\title{
Didactical engineering in France; an insider's and an outsider's view on its foundations, its practice and its impact
}

\author{
Claire Margolinas $^{1} \cdot$ Paul Drijvers $^{2}$
}

Accepted: 14 May 2015 / Published online: 3 June 2015

(C) The Author(s) 2015. This article is published with open access at Springerlink.com

\begin{abstract}
The notion of didactical engineering has influenced and characterized contemporary research in mathematics education in France to an important extent. In this paper, we address the following from an insider's and an outsider's perspective: (1) the way this notion is theoretically grounded, (2) the kinds of design research practices has it led to and is leading to, and (3) the way it relates to the design research paradigm. As a conclusion, we highlight similarities and differences between the two perspectives and recommend further discussions to the benefit of both didactical engineering from an insider's and an outsider's perspective.
\end{abstract}

\section{Introduction}

Design research (DR) is an important paradigm in educational research, particularly in mathematics education research (Prediger et al., this issue). However, the integration of design in mathematics education research may have different forms and purposes, depending on local research cultures. In writing this paper together, our experience is that it is interesting to shed light on these differences in order to better understand the different orientations in mathematics education research.

In France, didactical engineering (DE) has an important impact on the development in the field of mathematics

Paul Drijvers

p.drijvers@uu.nl

1 Université Clermont Auvergne, Université Blaise Pascal, EA 4281, ACTé, BP 10448, 63000 Clermont-Ferrand, France

2 Freudenthal Institute, Utrecht University, PO Box 85170, 3508 AD Utrecht, The Netherlands education research, and, in return, its use leads to further development of this notion and its corresponding research practices. The aim of this paper in this volume on design research is to describe the development and impact of $\mathrm{DE}$ in French research from an insider's point of view, and to enter into a debate with an outsider. In particular, we want to investigate (1) the way DE is theoretically grounded, with specific attention to its original foundation in the Theory of Didactical Situations (TDS) and more recent developments, (2) the kinds of design research practices DE has led to and is leading to, and (3) the way DE relates to the design research paradigm as it was shaped in the context of Dutch studies on realistic mathematics education (RME).

This paper is written by two authors who have been asked by the volume editors to contrast their views on didactical engineering and design research. Although this is a paper with two voices, it is not an 'equal opportunity' paper, since its main aim is to present the French didactical engineering approach. This explains the title: the French author is considered as an 'insider' in didactical engineering in France, whereas the Dutch author is named the 'outsider'. The outsider's perspective is the most prominent in the three sub-sections titled 'Intervention'. This being said, the two authors worked together on the paper, and none of the two represents the French or Dutch mathematics education community; they speak for themselves.

To prepare for a dialogue, Sect. 2 describes the outsider's perspective, which is rooted in the theory of RME and in design research methods. Next, the first author takes the lead in addressing didactical engineering and its development in France. Although the term 'didactical engineering' is not attached to one specific theory (Margolinas et al. 2011), the focus of the paper is mostly grounded in the framework of the Theory of Didactical Situation. In Sect. 3, didactical engineering is described in relation to the early 
work within TDS. Section 4 elaborates a paradigmatic example. In Sect. 5, we synthesize these differences and similarities and reflect on the initial questions.

\section{A Dutch view on realistic mathematics education and design research}

As the outsider is from the Netherlands and works at the Freudenthal Institute, his lens is formed by the general view of RME and by the methodology of design research as it is developed in the Dutch educational research tradition.

It is from a design research perspective that Freudenthal $(1973$; 1978) considers researchers in mathematics education as engineers. In his book Weeding and Sowing, for example, he describes his research group as follows.

[The author refers to a team of designers of science of mathematics education here:] The team I have in view is one of engineers rather than of people who claim or believe they carry on pure research, and the activity of this team [...] is curriculum development, a task that is as it were created for team work.

(Freudenthal, 1978, p. 174)

Indeed, we agree that design research in mathematics education can be characterized as a handyman's tinkering process of going back-and-forth between mathematical knowledge, theoretical notions, pedagogical notions, and practical task design ideas and skills. Theoretical knowledge is expected to develop through the design and evaluation of local instruction theories, which are based on results from research cycles of instructional design, teaching experiment and retrospective analysis (Gravemeijer, 1994, p. 150).

Realistic mathematics education is a domain-specific instruction theory for the teaching and learning of mathematics (Freudenthal 1983; De Lange 1987; Treffers 1987; Gravemeijer 1999, 2004; Van den Heuvel-Panhuizen \& Drijvers 2013). In this theory, mathematics is seen as a human activity, and students are provided with opportunities to mathematize realistic problems and to re-invent meaningful mathematics under the guidance of their teachers. The idea that mathematics should be meaningful is at the heart of RME philosophy. In fact, one may wonder if meaningful mathematics education would be a better label than RME, because the use of the word 'realistic' may be a source of confusion:

Although 'realistic' situations in the meaning of 'realworld' situations are important in RME, 'realistic' has a broader connotation here. It means students are offered problem situations which they can imagine. This interpretation of 'realistic' traces back to the
Dutch expression 'zich REALISEren', meaning 'to imagine'. It is this emphasis on making something real in your mind that gave RME its name. Therefore, in RME, problems presented to students can come from the real world, but also from the fantasy world of fairy tales, or the formal world of mathematics, as long as the problems are experientially real in the student's mind. (Van den Heuvel-Panhuizen and Drijvers, 2013, Realistic Mathematics Education)

As 'realistic' can refer to both real world problems and notions from formal mathematics, it is important to distinguish between horizontal and vertical mathematization (Treffers 1987). Mathematizing real-life situations in the sense of organizing these situations and finding solutions though mathematical means is called horizontal mathematization. Vertical mathematization concerns building up and reorganizing the mathematical system including the abstract world of symbols.

The metaphor of educational researchers as didactical engineers is at the heart of RME. Two design heuristics that are prominent in RME are didactical phenomenology and emergent modeling. Concerning didactical phenomenology, Freudenthal (1983) highlights the need to identify the phenomena for which mathematical concepts, structures, and ideas are created. It is these phenomena that may offer starting points for meaningful, realistic activities and problem situations that foster students' learning processes. A good question to start a design process, therefore, may be: what phenomena do the targeted mathematical concept help to organize and to understand?

After a phenomenological, mathematical and didactical analysis of the topic at stake, a didactical engineer needs to outline the different mathematical activities for students to do. A second, more recently developed design heuristic in this phase is called emergent modeling. It offers a way to consciously design and structure the targeted modeling processes by students (Gravemeijer, 1999, 2004). An emergent modeling approach starts with the identification of initial problems, which contains a context-specific model that refers to the paradigmatic context situation. Such problems may result from a didactical phenomenological analysis of the topic. Students are offered activities to explore this situation, while using and developing (initially informal) representations and models. After gathering more experience with similar problems, the activities invite students to gradually move away from the specific problems and, as a consequence, the models become part of a mathematical world of relations and reasoning:

According to the emergent-models design heuristic, the model first comes to the fore as a model of the students' situated informal strategies. Then, over time the model gradually takes on a life of its own. The 
model becomes an entity in its own right and starts to serve as a model for more formal, yet personally meaningful, mathematical reasoning. (Gravemeijer, 2004, p. 117)

The emergent modeling heuristic can be helpful to explicitly address the targeted process of gradual abstraction in the learning process.

The above theoretical notions and heuristics fit well into the methodology of design research (Cobb et al. 2003; Gravemeijer 1994; Design-Based Research Collective 2003; Plomp \& Nieveen 2013). Globally speaking, design research methodology is a research method in which cycles of a preliminary phase, a teaching experiment phase and a reflective phase inform each other and culminate in knowledge of why an intervention is successful or not. The design heuristics mentioned above are helpful in the preliminary phase, which includes the design of the intervention. In the second phase, the notion of the teaching experiment and its methodology may help researchers to carefully design the field test and gather appropriate data (e.g., see Steffe and Thompson 2000). In the third phase, the data analysis techniques (including, for example, making use of code schemes, software for qualitative data analysis, and inter-rater reliability) are well documented as well. Cobb and colleagues (2003) distinguish the following five common characteristics of DR (in the order in which they appear in this Volume's Introduction): (1) interventionist, (2) theory generative, (3) prospective and reflective, (4) iterative, and (5) ecologically valid and practice-oriented. In this Volume's Introduction, Prediger, Gravemeijer and Confrey describe the different 'strands' of, or views on DR in the Netherlands. The position taken in this paper, as far as the work in the Netherlands is concerned, relates to the Dutch DR work on RME (Gravemeijer 1994).

\section{French characteristics of didactical engineering: a starting point within the Theory of Didactical Situations}

In the decade that Freudenthal set up the RME theory, Brousseau (1972) crafted the early basis of TDS and the methodological basis of his study.

French mathematics didactics has a particular history which helps us to understand the similarities and differences between DE in France and the DR approach of RME in the Netherlands, which are at the core of this paper. We outline the history of modern mathematics education reform in order to understand the early work by Brousseau and the subtle relationship between theory and practice therein. This leads to a better understanding of the role of DE in the early French studies.

\subsection{Modern mathematics and the beginning of French mathematics didactics}

The modern mathematics curricular reform, also known as the New Math movement, was implemented in France in 1970 (and in other parts of the world during the same decade). It had a particular impact on the French society. France is the birthplace of Nicolas Bourbaki and most of its members were French. It was the great mathematician André Lichnerowicz who chaired the national mathematics curriculum commission (1966-1973), which designed the New Math French curriculum. The modern mathematics reform has dramatically shown that excellent mathematicians and psychologists (Jean Piaget's work was at the core of the reform) and a humanist ideology were not sufficient to establish a successful curriculum reform (Margolinas, 2005).

The 1970 national mathematics curriculum commission was aware of the fact that teacher preparation was insufficient to implement the reform. Hence, IREMs (Institut de Recherches sur l'Enseignement des Mathématiques) ${ }^{1}$ were established. These institutes, still active nowadays, ${ }^{2}$ had four major roles. The first was to bring together mathematics researchers in universities and mathematics teachers (at both primary and secondary levels), because 'modern math' was common at universities but new in primary and secondary schools. The second role was to set up research in mathematics education. The third was to provide resources for mathematics teaching, and the fourth role was to develop in-service teacher education.

At these times, mathematics education was conceived by university mathematicians as a field of application of ideas originated from domains such as mathematics, psychology, and pedagogy. Therefore, these Institutes were not submitted to the regular criteria of scientific research. Nowadays, IREMs' goals remain (a) to interpret and critically apply fundamental research into teaching (including epistemology, mathematics education, and educational sciences), (b) to support teacher educators, (c) to experiment with new pedagogical methods, and (d) to spread the positive and negative results of innovative research. ${ }^{3}$

\footnotetext{
${ }^{1}$ Institutes for Research in the Teaching of Mathematics.

2 www.univ-irem.fr.

${ }^{3}$ www.univ-irem.fr/spip.php?article6.
} 


\subsection{Brousseau's visionary work in the 1970s: the COREM as a 'didactron'}

In Bordeaux, Guy Brousseau took part in this general movement and was instrumental in the early development of IREMs.

[Brousseau] felt, though, that although an IREM was necessary, it was not sufficient for the level of scientific focus he envisioned. To achieve that level, he spent a lot of time and a huge amount of energy which jointly paid off in the creation of the COREM (Center for Observation and Research on Mathematics Teaching: 1973-1999). (Brousseau, Brousseau, \& Warfield, 2014, p. 4)

The COREM included a complete school (the Jules Michelet School in Talence, near Bordeaux) with 14 classes, with an adapted status: teachers were teaching parttime $(2 / 3)$ and were active participants in research projects for the remaining time (Salin \& Greslard 1998). This Centre for Observation is often misunderstood as an experimental school, a place to implement school innovation. In fact, "[the] COREM that we called our "Didactron" was a center for anthropological observation" (Brousseau, Brousseau, \& Warfield, 2014, p. 7).

What were the conditions identified by Brousseau for experiments in mathematics didactics? Under what conditions can an observer acquire objective knowledge without the interferences of his own values and intentions? Under what conditions was the observation acceptable for the teacher? Brousseau's solution was to connect teachers and researchers and to reduce the research object to students' behavior in specifically designed situations (Brousseau, 2010, p. 9). Even if teachers were observed, they were not the subject of observation. Since the research team designed the didactic situations as lessons to be taught, the observations focused on the situations themselves and students' behavior within these situations. As a consequence, the responsibility of teaching was shared between researchers and teachers. But their goals were different: the researcher's goal was to establish scientific results about mathematics didactics, whereas the teacher's goal was to teach mathematics in a satisfactory way in coherence with his or her views.

During the 25 years of existence of the COREM, no attempt was made to completely cover the French primary school mathematics curriculum, because the goal was never to provide a teaching model. On the contrary, "as Brousseau warns repeatedly and vigorously $[. .$.$] an attempt to$ use [the curriculum designed in the COREM] without [the] support [from the COREM] would be likely to have disastrous consequences" (Brousseau et al. 2014, p. 6). The modern math reform has shown that an uncontrolled modification of the mathematics teaching may indeed have negative consequences...

\subsection{Mathematics didactics as a 'normal science' and the place of didactical engineering}

One of the main features of the French paradigm of research in the didactics of mathematics is to give voice to basic research in this domain, which is not considered as a field of applied psychology or pedagogy.

Basic research is used here in the sense given by the International Council for Science (2004, p. 1):

Basic scientific research is defined as fundamental theoretical or experimental investigative research to advance knowledge without a specifically envisaged or immediately practical application. It is the quest for new knowledge and the exploration of the unknown. As such, basic science is sometimes naively perceived as an unnecessary luxury that can simply be replaced by applied research to more directly address immediate needs.

However the demarcation between basic research and applied research is not at all clear cut. In reality they are inextricably inter-twined. Most scientific research, whether in the academic world or in industry, is a hybrid of new knowledge generation and subsequent exploitation. Major innovation is rarely possible without prior generation of new knowledge founded on basic research. Strong scientific disciplines and strong collaboration between them are necessary both for the generation of new knowledge and its application.

Basic research focuses on the conditions which allow student knowledge to evolve and on the results of any experiment on student knowledge. The theoretical understanding of the way situations work is the aim and not the means to attain a practical goal (Brousseau 1975, cited by Perrin-Glorian, 1994, p. 101).

In attempts to answer this concern, we have to clarify the relationship between the theoretical framework and the experimental setting which involves both teachers and students and, in the case of the COREM, even an entire school for many years. A research which takes place in a school for a long period cannot indeed disengage itself from students' performance. In the case of the COREM, teacher educators and the teachers themselves were responsible for the final decisions about teaching, and standard test were used in order to ascertain that the students were learning the same skills as students in other French schools.

However, the purpose of the COREM was not a pragmatic one, but a way to develop scientific knowledge 
about teaching and learning mathematics and to "[gain] mastery over the phenomena themselves by producing them" (Chevallard, 1980, p. 150). Chevallard refers here to Bachelard (1934) who has coined the term phenomenotechnics, in order to distinguish "the productive aspects of science from its commonplace descriptive power" (Chevallard, 1980, p. 150). He affirms that "the didactics of mathematics really aim at being a phenomenotechnics in this sense" (ibid.). In this respect, we consider mathematics didactics as a-very young-science and its development as one of a normal science (Kuhn 1962), where theories tend to regroup around a paradigmatic core, inside which TDS's concepts and methods play a major role (Margolinas 1993).

It is in this perspective that Artigue $(1988,2009,2015)$ describes DE as similar to the work of the engineer, who is acquainted with the major scientific knowledge and accepts the scientific methods but at the same time is obliged to work with very complex objects, far from the simplified objects which are studied by science (Artigue, 1988, p. 283, our translation).

$\mathrm{DE}$ is considered as a means to didactical research (Artigue 1992) for different reasons. The first reason is the need to study students' knowledge as it develops in meaningful situations, which other authors may have considered as "interest dense situations" (Bikner-Ahsbahs et al. 2014, p. 97). These situations are not necessarily found in the regular teaching context. This seems to be very much in line with the idea that mathematics should be meaningful and connected to corresponding situations, which is also at the heart of RME philosophy.

The length of time involved in the experiment is important for this purpose. These meaningful situations cannot be fully understood through observations during a period of limited time length, because such a situation is defined not only by its interaction with the milieu but also by the didactical contract which has been previously shared in the class (Brousseau 1990). This is why many researchers have been engaged in long term research (not always an entire school for 25 years like the COREM, but 1 year or more with the same teacher, for instance). This kind of studies lead to what we may call 'proofs of existence': it is possible, under specific circumstances, to teach students a particular subject in a particular way. This does not mean that it is easy or even possible to create meaningful situations in a regular teaching setting but, similar to any scientific research which first needs laboratory experiments, meaningful situations are possible under particular research conditions.

The second reason to consider didactical engineering as an integral part of mathematics education research comes into play if we want to study teachers' work. If one has already piloted a didactical setting, and thus acquired a sequence which has been reproduced in experimental conditions (Artigue 1986), the results can be used as a means to focus on teachers' didactical choices, because much is known in advance about students' behaviour. One of the first studies of this kind was carried out by Brousseau and Centeno (1991), who used a well-developed and field tested teaching sequence on rational numbers to study teachers' didactical memories. Studying teachers' knowledge in a teaching environment is a research challenge; using established didactical engineering results allow researchers to minimize the variables.

The third reason to consider didactical engineering as an integral part of mathematics education research is that it allows researchers "[...] to think [about] the relationships between research and action on educational systems" (Artigue, 2009, p. 4). From a broader perspective, didactical engineering which involves teachers, students and researchers within a school and in the frame of a teaching experiment is the best setting to understand the real constraints and opportunities for teachers (Perrin-Glorian 2011). This approach may also reveal ways of teaching mathematics that are fruitful for students.

Intervention So far, we see that DE in France and the DR approach of RME in the Netherlands share some important characteristics. First, the importance of design is at the heart of both approaches, and researchers are sometimes seen as educational engineers (Artigue 1988; Freudenthal 1978). Second, there is a shared focus on students' knowledge in meaningful situations. To identify situations that have a potential for 'mathematical sense making', RME proposes the method of didactical phenomenology, which is very similar to the second step of DE research methodology, as we will see in the next section. Finally, both approaches stress the importance of in situ research in real classrooms and in collaboration with teachers, even if DE seems to acknowledge the different roles and responsibilities of the teachers involved in the research more explicitly. Still, the participatory observation methodology is shared between the two approaches.

In the meantime, an important difference between the French DE and Dutch RME-related DR seems to be their slightly different goals. Whereas RME primarily aims at providing pragmatic local instruction theories, TDSrelated DE has a more epistemic goal in establishing scientific basic knowledge about the teaching and learning of mathematics.

\section{A short description of a big adventure}

A paradigmatic example of interactions between didactical engineering and theoretical basic research can be found in the experiment on teaching the concept of fraction through situations (which is now available in English: Brousseau, 
Brousseau, \& Warfield, 2014). This experiment originated from the very beginning of the COREM during the 1970's.

The point of departure is a challenge: "The mathematics to be used for this experiment had to be both significant and challenging" (Brousseau, Brousseau, \& Warfield, 2014, p. 5). Thus, rational and decimal numbers, a mathematical concept which many students experience difficulties with at the end of primary school, was chosen. The hypothesis, which is the core of the experiment, is the possibility to teach mathematics in adidactic situations:

In adidactical situations it is the students who have the initiative and the responsibility for what comes from the situation. The teacher thus delegates part of the care for justifying, channeling and correcting the students' decisions to a milieu (Ibid, p. 174).

The preliminary analyses (Artigue 2015) begin with the determination of the different mathematical aspects of rational numbers. The crucial outcome of this study (see Brousseau, 1981, p. 49 Table 1) is the need to start with rational numbers as measurements, and elaborate this notion to rational numbers as linear mappings, as to generate the properties of rational numbers and to give meaning to their multiplication in particular.

[...] a major source of learning difficulty is that although rational numbers are used in several very distinct ways $[\ldots]$ they are generally taught as if all the meaning are equivalent. (Brousseau, Brousseau, \& Warfield, 2014, p. 5)

This analysis is compared to the actual curricular setting of rational and decimal numbers.

We have thus to imagine situations in which the different meanings of rational numbers naturally emerge as useful tools. The process of identifying such appropriate situations is similar to what was explained in Sect. 2 as didactical phenomenology (Freudenthal 1991): identify situations or contexts that "beg to be organized" by the mathematical means addressed in the teaching sequence.

It is thus possible to devise the different phases of the sequence of situations which characterize the different meaning of rational numbers. In fact, the main idea of the didactron is not only to imagine fundamental situationsthat is, the different situations corresponding to the different meanings of rational numbers - but also to design lessons which are discussed with the teachers and finally field tested in their classrooms.

The preliminary steps that we have described are the basis of a very detailed a priori analysis of the adidactical situation, which is devoted to the theoretical justification of each step. This analysis aims not only to predict students' possible reactions but also to understand their significance in relationship with the different meanings of the knowledge at stake, which is the goal of the lesson.

The a posteriori analysis is based on the data, which are collected in order to fulfill the particular scope of each research. The very detailed a priori analysis is the basis of the researcher's observation of the data, and the guideline for the data collection and data analysis. The observation of each situation depends strongly on this a priori analysis. For instance, if the a priori analysis considers the use of tools (e.g., a ruler) as significant in differentiating two procedures, the observer pays particular attention to the use of tools. In another case, the way students handle objects for counting purposes can be the focus of the analysis and, therefore, special attention is given to capturing students' handling of objects (by means of an appropriate position of the cameraman, for instance). There is no general methodology that can suit all research questions.

In the particular setting of the COREM it was also interesting to gather as much data as possible during experimental teaching scenarios: video and audio recordings, field notes, copies of students' work, etc. We should note here that the COREM was also set up to gather data which might be useful after the first research was completed, that is, to build an enriched archive for future researches. This is certainly a challenge; however, many studies have been done using this very rich collection of data ${ }^{4}$ and some are still ongoing (Brousseau \& Centeno 1991; Sensevy et al. 2005; Quilio 2012).

The last step of the research is the analysis of the data with different quantitative and qualitative methods which are strongly dependent on the research questions. This a posteriori analysis is compared to the a priori analysis: the concordances may contribute to the validation of some theoretical hypothesis. Conversely, what was not anticipated by the a priori analysis may be even more interesting because it may reveal a lack in the theoretical basis. Thus some of the results also inform the evolution and improvement of the TDS.

Intervention When we compare DE and DR research methodologies, we notice a similarity in their research phases, which include a phase of preliminary a priori analysis and design, a phase of teaching experiments, and a phase of retrospective analysis, although the wordings may be slightly different. The difference, however, is that DR highlights the cyclic character of this process, whereas this is less evident in DE, since the results of DE may be

\footnotetext{
$\overline{4450 \text { videos }}$ are online and are available for research purposes at the VISA website: http://visa.ens-lyon.fr/visa; paper documents are available at the University of Castellò (Spain): http://www.imac.uji.es/ CRDM/.
} 
less straightforward: different research questions may arise from DE, and the result is not the teaching sequence itself.

It is interesting to compare the a priori analysis, such an important phase in DE, with the notion of hypothetical learning trajectory (HLT) as it is used in DR. HLT is a theoretical construct that originally refers to "the teacher's prediction as to the path by which learning might proceed" (Simon 1995, p. 135). Here we primarily introduce it as a means for a designer to explicitly outline student activities and expected learning achievements in each of the phases of the learning trajectory based on a mathematical analysis of the topic at stake. Recent examples of how to use the notion of HLT in design research in mathematics education include the study by Stephan and Akyuz (2012) on integer addition and subtraction, the study by Doorman and colleagues (2012) on the function concept, and the case of statistics education presented by Bakker and Van Eerde (2015). Even if it is a limited representation, HLT in the former study is condensed into the form of a table of different phases in a teaching sequence, with the following column headings: tool, imagery, activity/taken-as-shared interest, possible topics of mathematical discourse, possible gesturing and metaphors. The labels of these columns may depend on the particular focus and framework of the study and will need further explanation. An advantage of making use of HLT is that it may foster an organized and structured way to sequence activities and to generate conjectures to be tested in a teaching experiment. Also, it helps to make explicit why one particular phase in the teaching sequence is expected to bring about a specific conceptual development in students' thinking, and why this naturally induces the core questions for the next phase.

Clearly, the notion of HLT relates to the cyclic character of DR, and to the aim to develop local instruction theories. In the meanwhile, we wonder if the HLT methodology may be helpful to further improve and exemplify the a priori analysis so crucial in the DE methods.

\subsection{Knowledge: distinction of savoir and connaissance}

In order to understand one of the outcomes of the above experiment from the perspective of TDS, we need a distinction which is difficult to make in English. In Latin languages, there are two words derived from the Latin sapere and conoscere (in French, savoir and connaissance) which correspond to only one word in English: knowledge. These words are used by Brousseau to highlight two different aspects of knowledge.

A piece of knowledge exists because it is useful for answering a question or to achieve something. This usefulness (Conne 1992) is very important. During the social construction of mathematics, knowledge is formulated, formalized, and written. The initial usefulness which has a meaning in specific situations generally becomes less explicit or even hidden, and mathematical knowledge may become a kind of formal knowledge. This process of institutionalization is not to be avoided; it serves to strengthen and summarize initial knowledge, which is an aspect of the didactic transposition (Chevallard 1985). The process, which connects knowledge in situation (connaissance) and institutional knowledge (savoir), works in both directions. During the construction of knowledge, the initial usefulness in situations is gradually forgotten. Knowledge is formalized, which is very important in order to create a coherent body of knowledge, known as mathematics. However, if you need to use mathematics to solve a problem, you have to understand its usefulness in situations, which is very different from understanding formal mathematics. Thus there is a dialectical link between formalized knowledge (savoir) and knowledge in situation (connaissance) (Margolinas 2014).

In these terms, the main question guiding Brousseau's adventures may be reformulated into the following: is it possible to learn mathematics in a way that assures the acquisition of both knowledge in situation (connaissance) and social knowledge (savoir)?

The conclusion of this process of didactical engineering and design research is that it is possible, under certain experimental conditions, to teach rational numbers with an aim to acquire both knowledge in situation (connaissance) and formalized knowledge (savoir). It has to be clear, however, that "the curriculum was not made to be used in other classes" (Brousseau et al., 2014, p. 7). In fact, Brousseau was very aware of the complexity of teachers' work. Thus, the transferability of this curriculum to any teacher without drastically changing its didactical properties was and is still an open question.

Intervention The distinction of connaissance and savoir seems to relate to the important distinction that is made in RME theory between horizontal and vertical mathematization. As explained in Sect. 2, horizontal mathematization refers to going back-and-forth between a situation and the world of mathematics. The type of knowledge that is acquired while doing so, therefore, may have a situated character and, in French terms, leads to connaissance. Vertical mathematization concerns mathematizing mathematics itself, and relates to building up an abstract (but meaningful!) 'building' of mathematics. As such, it leads to formalized and institutionalized knowledge, or savoir. The interplay between horizontal and vertical mathematization is something to pay attention to while teaching. The design heuristics of emergent modeling, presented in Sect. 2, may provide guidelines for designing education that facilitates the transition from connaissance to savoir. Also, the notion of guided reinvention provides explicit guidelines for fostering the transformation from connaissance to savoir. 


\subsection{Teacher's didactic memory: an example of follow-up}

The rational numbers curriculum experiment was initially devised to be reproduced two or three times with different classes.

We were therefore extremely surprised at the end of the experiment when the teachers expressed their desire to keep these lessons in the curriculum despite these difficulties. This reaction led us to understand that in certain cases jumps in complexity can be highly effective. (Brousseau et al., 2014, p. 8)

In fact, this very challenging curriculum was used by teachers in the many years COREM existed, that is, for over 25 years! The stability of this curriculum is very useful for follow-up studies, because students' mathematical procedures and knowledge evolution during the process are very well-known and predictable. This makes it possible for researchers to focus on teachers' activities.

The first of these studies was done by Julia Centeno (Brousseau \& Centeno 1991; Centeno 1995), who unfortunately passed away in 1992 before finishing her $\mathrm{PhD}$ thesis. She studied what she called teacher's didactical memory. She shows that, in order to link the lessons and to ensure the progression of knowledge from one lesson to another, the teacher needs to recall some facts, observed during the previous lessons, that are specific of the knowledge at stake. One of the hypotheses (Centeno, 1995, pp. 19-21) is that a teacher's difficulty to articulate students' knowledge increases when the teacher wants to provide meaning to the knowledge. When the knowledge is taught using the structure of formalized knowledge (savoir), it is easy for the teacher to recall the order of the pieces of knowledge and the procedures involved. But when the knowledge emerges informally and is linked to students' adaptation to adidactical situations, the teacher has to recall how the students have dealt with these situations and what has already been mentioned, formulated, formalized, etc. This puts high demands on the teachers' skills.

Centeno studied how teachers deal with the 'recall phases' during which they remind students the findings of the previous lessons. First, she studied how teachers deal with these phases in regular school conditions in Spain. Results indicate that during the recall phase, teachers often remind pupils of the formalized knowledge at stake rather than the knowledge in situation which pupils encountered.

Next, the recall phase was studied at the COREM within the rational number curriculum under various experimental conditions that shared one feature: more than one teacher taught the lessons. Under these experimental conditions, teachers needed to share information on what happened during the lesson taught by others. Through these exchanges, teachers who were engaged in the rational numbers curriculum were able to recall students' knowledge in situation and to carry out the necessary follow-up discussions or activities with the class.

This work by Centeno is one of the first which experimentally studied the institutionalization process and the difficulty for the teacher to articulate informal and formal knowledge within a coherent curriculum.

\subsection{Didactical engineering and teachers' practices}

Thanks to a better understanding of teacher's activities (See the ESM special issue: Laborde \& Perrin-Glorian, 2005), the interest in didactical engineering has shifted from the study of students' learning to the study of teacher's knowledge and activities. It has also triggered a new interest in the possible benefits from researches in regular teaching practices. The research of didactic engineering in the interface of practice and research, which focuses on the theoretical basis of didactical engineering and its outcomes (Margolinas et al. 2011), was the theme of the 15th Summer School of Mathematics Didactics.

As stated clearly by Perrin-Glorian (2011), didactical engineering is a method (a) to better understand teaching, and (b) to reflect on the production of resources for teaching and teacher training. She makes a plea for 'second generation engineering' which takes into account the problem identified by Rouchier and Steinbring (1989):

Even under well-controlled conditions for producing theoretical knowledge in the laboratory, putting this theory in action becomes a problem in itself. This problem is one of curriculum and methods, in the sense that a particular engineering must be generated. (p. 211)

On the one hand, design research aims at validating the effects of experimental condition on students' knowledge (on both aspects: connaissance and savoir). On the other hand, design research can also study the adaptability and transfer of the didactical engineering process to ordinary teaching conditions. The two goals may correspond to different time periods, as it is the case in the above study, with a time gap between the design and implementation of the first studies (during the 1970's) and the study of teachers' roles (during the 1990's). However, if both perspectives are taken into account right from the beginning of the didactical engineering, this also affects the study itself. PerrinGlorian suggests the term 'didactical engineering for development' to designate this type of research (Perrin-Glorian, 2011, p. 69).

Conversely, didactical engineering, which was originally meant to study students' learning, is now often used to investigate teachers' professional development, with a 
special focus on teachers' work with resources (Gueudet \& Trouche 2009; 2012) and on didactical engineering (Margolinas \& Wozniak 2014).

\section{Comparing and contrasting didactical engineering in France and design research in the Netherlands}

The aim of this paper, as we phrased it in the introduction, is to describe the development and impact of the 'ingénierie didactique' in French research on mathematics education. In particular, we want to investigate (1) the way this notion is theoretically grounded, with specific attention to its foundation in the Theory of Didactical Situations, (2) the kinds of design research practices it has led to and is leading to, and (3) the way DE relates to the Dutch RMErelated design research paradigm.

Concerning the first question on theoretical foundations, we conclude that didactical engineering can be seen as a methodological approach based on a theoretical framework which guides the design research at stake. This being said, a didactical engineering approach of course fits better into some theoretical perspectives than others. The French experiences show that DE is an excellent fit with Brousseau's Theory of Didactical Situations.

With respect to the second question on research practices, the paradigmatic work described in Sect. 4 shows the kinds of design research practices the notion of didactical engineering has led to. These examples support the idea that didactical engineering may encompass a much broader range of research than it was foreseen at its beginning. In adopting the position of an engineer, educational researchers have gained access to research which not only provides teachers with a design that cannot be changed, but also helps to study and to model teachers' practices.

While answering the third question on the relationships between the French DE and DR as it is used in the Dutch RME context, we first noticed similarities in the importance of design and the importance of a mathematical analysis of the topic at stake. Both TDS and RME embrace the metaphor of educational researchers as engineers. The RME idea of finding meaningful points of departure for learning is quite similar to the DE methodology used by Brousseau and other French researchers (Barquero \& Bosch, 2015, in press). Both approaches share an interest in what is called knowledge in situation (TSD) or paradigmatic context situations (RME). Finally, the relationship between the theoretical distinction of connaissance and savoir and the RME notions of horizontal and vertical mathematizations deserve further exploration.

From the methodological perspective, similarities can be found in the different research phases of the two approaches, which include a phase of preliminary analysis and design, a phase of teaching experiments, and a phase of retrospective analysis, although the wordings used may be slightly different. Also, the two approaches share an interest in in situ observations in collaborations with teachers. A more detailed confrontation of the two notions of a priori analysis and hypothetical learning trajectory may be interesting for both approaches. Finally, a rigorous methodology is indispensable in both approaches. As a global trend, we see that didactical engineers are no longer just 'tinkering' with mathematical tasks, but complement their toolkits with methodological knowledge beyond design heuristics, and with quantitative methods in addition to qualitative methods.

However, DE and DR seem to differ in the priority of research aims and goals. For TDS, the priority is to gather understanding about the phenomena which derive from teaching mathematics. Thus, to teach mathematics in a way that corresponds to the work of the mathematicians is a challenge (Brousseau et al. 2014) which has to be documented by research with primarily epistemic aims. RME's notions of didactical phenomenology and guided reinvention have the work of the mathematician as their origin and consider that mathematics teaching should be taught in a corresponding way; as such, it has a pragmatic aim of developing local instruction theories. This being said, the authors' perception is that on the one hand, the original priority within the French DE given to theoretical proceedings nowadays has been complemented by an interest in pragmatic results. On the other hand, the Dutch RME-related DR has moved from a pragmatic stance to include theoretical aims as well. In this sense, the two approaches seem to be converging rather than diverging.

As a consequence, research methods are different as well. DR highlights the cyclic character of the research process, whereas the result of DE might be less straightforward: different research may arise from $\mathrm{DE}$, and the result is not the teaching sequence itself. As RME consider engineering as the goal of educational research, TDS consider both basic and applied research as its goals. Hence RME has developed more explicit guidelines to offer to these engineers, with the notions of guided reinvention and emergent modeling.

One other difference between the two is their relation to theoretical frameworks. Whereas DE seems to be closely related to specific theories such TDS or anthropological didactics theory, DR in its different forms seems to have a wider and more heterogeneous theoretical basis (Godino et al. 2013; Plomp \& Nieveen 2013).

To summarize this inventory of differences and similarities of the French DE approach and the Dutch RME-related DR, we briefly review each of them in the light of the five DR characteristics provided by Cobb et al. (2003): 
1. Interventionist: clearly, both the French DE and the Dutch RME-oriented DR have an interventionist character, in which teachers are heavily involved.

2. Theory generative: to generate theory originally was more of a core aim for the French DE than for the Dutch approach. Gradually, however, the two seem to move towards each other in this respect.

3. Prospective and reflective: both approaches are prospective in the sense that hypotheses are phrased beforehand and are used to guide the design, and reflective in the sense that the studies' results inform new hypotheses and, possibly, new designs.

4. Iterative: the iterative characteristic of the work is more prominent in the Dutch RME-based DR than in the French DE. This is related to the priority of theoretical and pragmatic goals.

5. Ecologically valid and practice-oriented: ecological validity is at the heart of both approaches. As indicated above, the orientation towards practice is more prominent in the Dutch approach compared to the French one.

Of course, these general remarks do not do justice to the differences that exist both within DE and within DR. For example, the DR carried out by Doorman and colleagues (2012) takes an RME perspective. As such, it may be seen as DR (RME) in terms of the abbreviations used by Godino et al. (2013), but it can also be considered as an example of DE. The distinction made by Perrin-Glorian (2011) between development-oriented DE and research-oriented DE may be helpful here: in some examples of DE studies, the development component seems to be more important than the research lens, and with respect to the general methodological aspects mentioned in the previous phrase, DR may have much to offer to DE.

This brings us to our final conclusion: didactical engineering has played an important and fruitful role in French design research on mathematics education, and still continues to play such a role. In the meantime, a further exchange of research practices within the international mathematics education research community may be helpful to further exploit the potential of research and to further improve the quality and the impact of its results.

Open Access This article is distributed under the terms of the Creative Commons Attribution 4.0 International License (http://creativecommons.org/licenses/by/4.0/), which permits unrestricted use, distribution, and reproduction in any medium, provided you give appropriate credit to the original author(s) and the source, provide a link to the Creative Commons license, and indicate if changes were made.

\section{References}

Artigue, M. (1986). Etude de la dynamique d'une situation de classe : une approche de la reproductibilité. Recherches en Didactique des mathématiques, 7(1), 5-62.
Artigue, M. (1988). Ingénierie didactique. Recherches en Didactique des Mathématiques, 9(3), 281-308.

Artigue, M. (1992). Didactique engineering. In R. Douady \& A. Mercier (Eds.), Research in Didactique of mathematics (pp. 41-66). Grenoble: La pensée sauvage.

Artigue, M. (2009). Didactical design in mathematics education. In C. Winslow (Ed.), Nordic research in mathematics education. NORMA 08 (pp. 7-16). Rotterdam, Boston, Taipei: Sense Publishers.

Artigue, M. (2015). Perspective on design research: The case of didactical engineering. In A. A. Bikner, K. Knipping, \& N. Presmeg (Eds.), Approaches to qualitative research in mathematics education (pp. 467-496). Dordrecht, Heidelberg, New York, London: Springer.

Bachelard, G. (1934). Le nouvel esprit scientifique (PUF, 2003 edn.). Paris: Alcan.

Bakker, A., \& Van Eerder, D. (2015). An introduction to designbased research with an example from statistics education. In A. A. Bikner, K. Knipping, \& N. Presmeg (Eds.), Approaches in qualitative research in mathematics education (pp. 429-466). Dordrecht, Heidelberg, New York, London: Springer.

Barquero, B., \& Bosch, M. (2015, in press). Didactic engineering as a research methodology: From fundamental situations to study and research paths. In A. Watson \& M. Otani (Eds.), Task design in mathematics education. Dordrecht, Heidelberg, New York, London: Springer.

Bikner-Ahsbahs, A., Prediger, S., \& Halverscheid, S. (2014). Introduction to the theory of interest-dense situations (IDS). In A. Bikner-Ahsbahs \& S. Prediger (Eds.), Networking of theories as a research practice in mathematics education (pp. 97-113). Dordrecht, Heidelberg, New York, London: Springer.

Brousseau, G. (1972). Processus de mathématisation. In La mathématique à l'Ecole Elémentaire (pp. 428-442). Paris: APMEP.

Brousseau, G. (1975). Exposé au colloque "L'analyse de la didactique des mathématiques". Bordeaux: IREM de Bordeaux.

Brousseau, G. (1981). Problèmes de didactique des décimaux : deuxième partie. Recherches en Didactique des Mathématiques, 2(1), $37-127$.

Brousseau, G. (1990). Le contrat didactique: le milieu. Recherches en Didactique des Mathématiques, 9(3), 309-336.

Brousseau, G. (2010). Le centre d'observation et de recherches sur l'enseignement des mathématiques. http://guy-brousseau.com/lecorem/. Retrieved 28 Feb 2015.

Brousseau, G., Brousseau, N., \& Warfield, G. (2014). Teaching fractions through situations: A fundamental experiment. Dordrecht, Heidelberg, New-York, London: Springer.

Brousseau, G., \& Centeno, J. (1991). Rôle de la mémoire didactique de l'enseignant. Recherches en Didactique des Mathématiques, 11(2/3), 309-336.

Centeno, J. (1995). La mémoire didactique de l'enseignant (Textes établis par Claire Margolinas, préface et notes de Guy Brousseau). Bordeaux: LADIST.

Chevallard, Y. (1980). The didactics of mathematics: Its problematic and related research. Recherche en Didactique des Mathématiques, 2(1), 146-158.

Chevallard, Y. (1985). La transposition didactique. Du savoir savant au savoir enseigné. Grenoble: La pensée sauvage.

Cobb, P., Confrey, J., DiSessa, A., Lehrer, R., \& Schauble, L. (2003). Design experiments in education research. Educational Researcher, 32(1), 9-13.

Conne, F. (1992). Savoir et connaissance dans la perspective de la transposition didactique. Recherches en Didactique des Mathématiques, 12(2-3), 221-270.

De Lange, J. (1987). Mathematics, insight and meaning. Utrecht: OW\&OC. 
Design-Based Research Collective. (2003). Design-based research: An emerging paradigm for educational enquiry. Educational Researcher, 32(1), 5-8.

Doorman, M., Drijvers, P., Gravemeijer, K., Boon, P., \& Reed, H. (2012). Tool use and the development of the function concept: From repeated calculations to functional thinking. International Journal of Science and Mathematics Education, 10, 1243-1267.

Freudenthal, H. (1973). De niveaus in het leerproces en de heterogene leergroep, met het oog op de middenschool (Levels in the learning process and the heterogeneous groups, considering middle school). In Gesamtschule Conferentie 1973 (pp. 88-99). Purmerend: Muusses.

Freudenthal, H. (1978). Weeding and sowing. Dordrecht: Reidel.

Freudenthal, H. (1983). Didactical phenomenology of mathematical structures. Dordrecht: Reidel.

Freudenthal, H. (1991). Revisiting mathematics education. Dordrecht: Kluwer Academic Publishers.

Godino, J., Batanero, C., Contreras, A., Estepa, A., Lacasta, E., \& Wilhelmi, M. R. (2013). Didactic engineering as design-based research in mathematics education. In B. Ubuz, Ç. Haser \& M. A. Mariotti (Eds.), Proceedings of the Eighth Congress of the European Society for Research in Mathematics Education (pp. 2810-2819). Ankara: Middle East Technical University.

Gravemeijer, K. (1994). Developing realistic mathematics education. Utrecht: CD- $\beta$ Press/Freudenthal Institute.

Gravemeijer, K. (1999). How emergent models may foster the constitution of formal mathematics? Mathematical Thinking and Learning, 1(2), 155-177.

Gravemeijer, K. (2004). Local instruction theories as means of support for teachers in reform mathematics education. Mathematical Thinking and Learning, 6, 105-128.

Gueudet, G., \& Trouche, L. (2009). Towards new documentation systems for mathematics teachers? Educational Studies in Mathematics, 71, 199-218.

Gueudet, G., \& Trouche, L. (2012). Teachers' work with resources: Documentational geneses and professional geneses. In G. Gueudet, B. Pepin, \& L. Trouche (Eds.), From text to 'Lived' resources (pp. 23-41). Dordrecht, Heidelberg, New York, London: Springer.

International Council for Science. (2004). The value of basic scientific research. http://www.icsu.org/publications/icsu-positionstatements/value-scientific-research/549_DD_FILE_Basic_Sciences_12-04.pdf.

Kuhn, T. S. (1962). The structure of scientific revolutions. Chicago: Chicago University Press.

Laborde, C., \& Perrin-Glorian, M. J. (Eds.). (2005). (Special Issue) Teaching situations as object of research: Empirical studies within theoretical perspectives. Educational Studies in Mathematics, 59(1-3).

Margolinas, C. (1993). De l'importance du vrai et du faux dans la classe de mathématiques. Grenoble: La pensée sauvage.

Margolinas, C. (2005). Essai de généalogie en didactique des mathématiques. Revue suisse des sciences de l'éducation, 27(3), 343-360.

Margolinas, C. (2014). Connaissance et savoir Des distinctions frontalières? In P. Losego (Ed.), Actes du colloque "Sociologie et didactiques: vers une transgression des frontières", 13 et 14 septembre 2012 (pp. 17-44). Lausanne: Haute école pédagogique de Vaud. http://www.hepl.ch/sociodidac.

Margolinas, C., Abboud-Blanchard, M., Bueno-Ravel, L., Douek, N., Fluckiger, A., Gibel, P., et al. (Eds.). (2011). En amont et en aval des ingénieries didactiques. Grenoble: La pensée sauvage.

Margolinas, C., \& Wozniak, F. (2014). Early construction of number as position with young children: A teaching experiment. ZDMThe International Journal on Mathematics Education, 46(1), 29-44.

Perrin-Glorian, M. J. (1994). Théorie des situations didactiques: Naissance, développements, perspectives. In M. Artigue, R. Gras, C. Laborde, \& P. Tavignot (Eds.), Vingt ans de didactique des mathématiques en France (pp. 97-147). Grenoble: La pensée sauvage.

Perrin-Glorian, M. J. (2011). L'ingénierie didactique à l'interface de la recherche avec l'enseignement. Vers une ingénierie didactique de deuxième génération? In C. Margolinas, M. Abboud-Blanchard, L. Bueno-Ravel, N. Douek, A. Fluckiger, P. Gibel, F. Vandebrouck, \& F. Wozniak (Eds.), En amont et en aval des ingénieries didactiques (pp. 57-77). Grenoble: La pensée sauvage.

Plomp, T., \& Nieveen, N. (2013). Educational design research. Enschede: SLO

Quilio, S. (2012). Une forme caractéristique de condition de l'étude dans la réalisation d'une ingénierie didactique en mathématiques à l'école primaire. Education et didactique, 6(2), 9-26.

Rouchier, A., \& Steinbring, H. (1989). The practice of teaching and research in didactics. Recherches en Didactique des Mathématiques, 9(2), 189-219.

Salin, M. H., \& Greslard, D. (1998). La collaboration entre chercheurs et enseignants dans un dispositif original d'observation de classes, et lors de la préparation d'une séquence de classe, le Centre d'Observation et de Recherche sur l'Enseignement des Mathématiques (COREM). In Les liens entre la pratique de la classe et la recherche en didactique des mathématiques, 50e Rencontre de la CIEAM. http://guy-brousseau.com/wp-content/ uploads/2010/08/Collaboration-entre-chercheurs-et-enseignants. pdf. Retrieved 28 Feb 2015.

Sensevy, G., Forest, D., \& Barbu, S. (2005). Analyse proxémique d'une leçon de mathématiques: Une étude exploratoire. Revue des sciences de l'éducation, 31(3), 659-686.

Simon, M. A. (1995). Reconstructing mathematics pedagogy from a constructivist perspective. Journal for Research in Mathematical Education, 26, 114-145.

Steffe, L. P., \& Thompson, P. W. (2000). Teaching experiment methodology: Underlying principles and essential elements. In R. A. Lesh \& A. E. Kelly (Eds.), Research design in mathematics and science education (pp. 267-307). Hillsdale, NJ: Erlbaum.

Stephan, M., \& Akyuz, D. (2012). A proposed instructional theory for integer addition and subtraction. Journal for Research in Mathematical Education, 43, 428-464.

Treffers, A. (1987). Three dimensions. A model of goal and theory description in mathematics instruction: The Wiskobas project. Dordrecht: Reidel.

Van den Heuvel-Panhuizen, M., \& Drijvers, P. (2013). Realistic mathematics education. In S. Lerman (Ed.), Encyclopedia of mathematics education. Dordrecht, Heidelberg, New York, London: Springer. 